\title{
THINKING ABOUT STRATEGY
}

by

David S. Meyer, UC-Irvine and Suzanne Staggenborg, McGill University

Prepared for delivery at American Sociological Association, Collective Behavior/Social Movement Section’s Workshop, “Movement Cultures, Strategies, and Outcomes,” August 9-10, 2007, Hofstra University, Hempstead, New York. 
On June 24, 2007, a home-made bomb failed to explode near the home of Dr. Arthur Rosenbaum, a research opthamologist at UCLA. The Animal Liberation Brigade claimed credit for the bomb, issuing a communique to an animal rights website. According to the Brigade: 130am on the twenty forth of june: 1 gallon of fuel was placed and set a light under the right front corner of Arthur Rosenbaums large white shiney BMW. He and his wife....are the target of rebellion for the vile and evil things he does to primates at UCLA. We have seen by our own eyes the torture on fully concious primates in his lab. We have heard their whimpers and screeches of pain. Seeing this drove one of us to rush out and vomit. We have seen hell and its in Rosenbaums lab. Rosenbaum, you need to watch your back because next time you are in the operating room or walking to your office you just might be facing injections into your eyes like the primates, you sick twisted fuck” (Animal Liberation Brigade, 2007, sic).

The bomb alerted scientists about dangers they might face if they used certain animals in their experiments, and signaled to animal rights sympathizers that aggressive action was possible. It also engaged a range of authorities. The FBI's counterterrorism division in Los Angeles responded, offering a reward of $\$ 110,000$ for information leading to the arrests and convictions of those responsible for the attack (Gordon 2007).

On the same day that the FBI announced its reward, The New York Times published an analysis of the recent influence of the animal rights movement-in its food and dining section. According to the Times, the influence of the movement reflected the "maturation and sophistication” of animal activists (Severson 2007). Over the past twenty-five years, activists 
have moved from guerilla media campaigns outside fast food restaurants and "rescues" of farm animals bred for consumption to "more subtle tactics, like holding stock in major food corporations, organizing nimble political campaigns and lobbying lawmakers.” Although core activists oppose not only animal experimentation, but also meat-eating, their political efforts highlight stopping the consumption of veal and foie gras, and working in alliance with celebrity chefs to create markets for cage-free eggs and humanely raised meats and eggs. "Instead of telling it like it is, we're learning to present things in a more moderate way," explained one-time animal rescuer Gene Baur. "Would I love everyone to be vegan? Yes. But we want to be respectful and non-judgmental” (Severson 2007).

These recent reports on animal rights efforts underscore several elements of social movement strategy. First, strategy includes decisions about tactics, claims, targets, and alliances, and these decisions are interrelated. Vegan absolutists are not meeting with restaurant owners to suggest new suppliers for lamb and eggs, and firebombers are not scheduling meetings with scientists. Second, the intervention of state authorities changes the available options for everyone. Counterterrorist investigation of those who practice violent tactics can exacerbate schisms within the animal rights movement. Third, movements are not unitary actors. Even as some activists are marching toward an institutional accommodation with people they might previously have viewed as enemies, others continue to attack these same people. Fourth, strategic decisions are debatable-and generally debated. Whereas some activists see the cultivation of demand for cage-free eggs, for example, as a leading edge for broader education about how animals are treated, others view it as a sell-out that compromises the movement. These general points, of course, are not limited to the contemporary campaigns around 
animal rights and welfare. Social movement strategy sits at the intersection of structure and agency, as activists seek to respond to changing political and cultural circumstances and maximize their impact. As in sports, politics, and business, we think strategic decisions affect organizational well-being as well as the attainment of external goals. Strategic decisions are debated, justified, second-guessed, and often reconsidered. Yet the impacts of movement strategies are difficult to assess, and it's hard to know with any certainty what the long and shortterm outcomes of the road not taken might have been and how available alternative strategies really were. Among activists, debates over strategic choices and outcomes carry over to future battles.

As academic analysts, we have a somewhat different role. We want to develop a conception of strategy that is rigorous enough to understand how activists make decisions and what the consequences of those decisions are, and how we might honestly evaluate alternatives. The existing literature on social movements affords us considerable room to sketch out an analytical strategy; indeed, we lack even a consensual definition of social movement strategy. In this paper, we offer the beginnings of a theoretical framework for understanding and evaluating the content of social movement strategy. We pay particular attention to developing an operational conception of social movement strategy and the constraints that activists face in making strategic decisions.

Thinking about strategy in social movements is thus of critical importance to both activists and scholars. For activists, strategy refers to choices about claims, issues, allies, frames, identity and presentation of self, resources, and tactics. They act as though these choices matter, and we generally assume that they do--although the cumulation of activist knowledge is 
inevitably ad hoc. Although it's heuristically attractive to think about each decision about an issue, tactic, or alliance as discrete, the choices of the past heavily constrain the real possibilities in the present. Activists are precluded from exploring, much less employing, an extensive inventory of choices by limits on their expertise, resources, and identities, as well as by the exigencies of the moment. Activists make choices, of course, but not just as they please. They pick not from an elaborated catalogue of theoretical possibilities, but from a more limited "repertoire of contention," as Charles Tilly has demonstrated. To understand the impact of strategic decisions, we need to recognize the constraints on possibilities that confront activists. We need to ask how the repertoire of contention is limited, how and why different groups select various tactics, and what the consequences of their choices are. Both proximate and long-term outcomes are affected by the strategic decisions of activists as well as by the responses of allies, bystanders, authorities, and opponents, and this constrains the choices of the future.

Despite the obvious importance of strategy, the literature on social movements suffers from a deficit of systematic theoretical and empirical work on the topic. Indeed, Gamson's classic (1990 [1975]) Strategy of Social Protest focused on organizational characteristics, such as size and levels of bureaucracy, and purposefully neglected changes in opportunities over time. There are, to be sure, many case studies that examine particular strategic choices or capacities (e.g., Barkan 1979; Bernstein 1997; Ganz 2000) and various theoretical offerings of definitions and approaches (e.g., Freeman 1979; Ganz 2004; Jasper 2004; Jenkins 1981; Rucht 1990; Taylor and Van Dyke 2004; Turner 1970). But we have, collectively, been slow to develop a larger synthetic understanding of these choices. For example, researchers have identified various strategic dilemmas that activists confront (e.g., Jasper 2004), but we have not yet developed an 
understanding of how such dilemmas are interrelated and how their solutions are constrained. One of the difficulties we find in attempts to deal with the topic is that an analyst can place virtually any decision about almost anything under the rubric of strategy. Here, we aim to provide a more manageable way of conceptualizing strategy and thinking about influences on strategic choices and outcomes.

In brief, our approach identifies several major elements of strategic decision-making: the demands or claims made by collective actors; the arenas or venues of collective action; and the tactics or forms of collective action. All of these choices imply the selection of particular targets of collective action. We clarify different levels of strategic action and influences on strategy, ranging from the large-scale cultural and political to movement community and organizational level dynamics. We identify key questions about the selection and impact of strategy and we offer an operational way of thinking about strategic choices, comprised of the visible expression of decisions about claims, venues, and tactics. By thinking about strategy as comprised of multiple decisions by multiple actors, and employing different levels of analysis, we argue that it is possible to trace the range of factors affecting the expression of strategic choices and their consequences.

Moreover, we recognize that activists make strategic decisions mindful of multiple and distinct audiences, including various authorities, movement opponents, organized allies and potential allies, supporters with varying degrees of commitments, and potential supporters and opponents. Importantly, decisions that appease (or provoke) one audience are likely to produce exactly the reverse response from other audiences. In making strategic decisions, activists effectively choose their allies and opponents, and each decision constrains the next round of 
decisions.

We can think about strategic choices as exercises a group takes in positioning itself in relationship to potential allies and opponents. Metaphorically, a group takes a decision that moves it across a field filled with a range of other actors, both institutional and extrainstitutional. Each strategic decision moves that group in relation to other actors that are also making choices at the same time. For example, an animal rights groups may take an absolutist stand on meat-eating that secures the loyalty and commitment of its supporters while simultaneously distancing the group from policymakers and a potential influence on policy. Groups quickly become entangled in a web of relationships that make strategic innovation more difficult, for dramatic moves always carry the risk of rupture.

We begin with an expanded discussion of our conceptual approach before examining different levels of influences on strategic choices and outcomes.

\section{CONCEPTUALIZING STRATEGY}

Strategy is the "overall plan for action, the blueprint of activities with regard to the mobilization of resources and the series of collective actions that movements designate as necessary for bringing about desired social changes" (Jenkins 1981:135). Strategic actors survey their resources, goals, and available opportunities, and try to make matches that maximize their influence. Importantly, however, influence is multidimensional, and plays out over both long and short time frames. A decision may affect not only the response of policymakers, but also the potential to mobilize resources in the future. The strategic decision maker has to balance sometimes conflicting interests and pressures (Meyer 2007). 
To understand how strategic choices are made, we point to a series of interactions within the movement and between movement actors and targets, opponents and potential allies. Activists become familiar with strategies, assess their opportunities, and position themselves for new rounds of collective action in particular contexts and as a consequence of their relationships with actors inside and outside the movement. This is an iterative process, dependent upon the reactions of others engaging the same sets of issues and constituencies, which can alter the next round of opportunities and constraints.

Collective action demands, arenas, and tactics are three key elements of strategy, which each involve the selection of targets, decisions about timing, and various types of relationships and strategic dilemmas. ${ }^{1}$ These choices are naturally related, and each decision opens up some strategic possibilities, while foreclosing others.

\section{Demands}

One of the basic strategic choices that movement actors make concerns the demands or claims they will put forward--claiming particular rights, calling for injustices to be redressed, arguing for needed political and social changes. Such demands are related to movement goals, but they are also strategic choices about which goals to pursue at what time and in what manner. Virtually all social movement organizations have multiple concerns, and must make decisions about what to emphasize at any given time. The animal rights activists referenced above, for example, have a comprehensive agenda, but may choose to press only the least contentious

\footnotetext{
${ }^{1}$ In identifying these three strategic elements, we recognize other ways of thinking about the components of strategy. Ganz (2004:181), for instance, identifies “targeting, timing, and tactics” as key elements. In our scheme, targeting and timing can be analyzed with regard to demands, arenas and tactics. Our goal is to provide a parsimonious conception of the major negotiations involved in movement strategy.
} 
elements of that agenda, such as creating a market for cage-free eggs, rather than banning fur, leather, and meat. They want to choose the piece of their concerns that best serves their mobilizing and policy goals, allowing for substantive progress on matters of policy while maintaining the attention of their supporters. ${ }^{2}$ Moreover, individual activists and organizations also choose priorities among broad issue areas, which change over time. Thus, the same environmental group with the same concerns may battle nuclear power in the 1970s, toxic waste in the 1980s, and global climate change in the contemporary era. Over long activist careers, similarly, individuals may work for civil rights in the 1960s, environmental protection in the 1970s, against military intervention in Latin America in the 1980s, and for reproductive rights in the 1990s, without changing their basic world views (Fendrich 1993; Meyer and Whittier 1994; Whalen and Flacks 1989).

In making demands, movement actors appeal for the attention of a variety of actors in a multi-organizational field: supporters called upon to mobilize in response to threats or opportunities; potential allies asked to support movement claims; mass media encouraged to cover movement issues; opponents challenged by the demands; and authorities or other targets pressed to respond. Activists must choose not only what issues to pursue, but how to describe or frame what they are doing. They can emphasize one issue as part of a much larger one, or as a reasonably discrete concern, and as more or less threatening to authorities and other elites (cf. Ash 1972:230). Issues can be framed in ways that incorporate the concerns of a variety of groups, or they can be presented narrowly to address only the issues of a particular constituency. These choices have consequences for the ability to attract participants, form coalitions, persuade

${ }^{2}$ Gornick \& Meyer (1998), in writing about the feminist movement against sexual violence, term this piece of an agenda an "issue frontier." 
allies, and influence authorities. Choices about demands and their targets are shaped by expectations about the responses of targets and bystanders as well as by their actual responses. The history of past claims-making and experience with targets and other actors is thus critical to subsequent demands.

Gamson (1990) argues that a strategy of "thinking small” increases success, but of course, those successes are modest; groups that attempt to "displace their antagonists" are less likely to succeed than those with more modest goals. But Gamson (1990:49) found "no clear evidence of an independent effect of multiple-issue demands" on success rates, and he notes that the demands of almost any group can be framed as either single or mutiple-issue. Gerhards and Rucht (1992) argue that "mobilization capacity” is increased when framing demonstrates how issues are interrelated, thereby appealing to multiple constituents with a wide range of concerns. At the same time, we recognize that embedding one issue in a broader array of issues can scare off both potential supporters and authorities. Movements face tradeoffs in choosing among broad demands to attract widespread support, either radical or particular claims to please narrow constituencies, or moderate claims to appease authorities. Relationships with one set of actors, such as elite allies, can threaten those with another group, such as grassroots constituents. To understand changing movement demands, we need to assess interactions with other actors in the multi-organizational field and how these relationships, and the positions of movement actors, shift over time.

Arenas

Movement actors need to select arenas or venues in which to press their claims. Each 
venue provides differential access to different targets and audiences, and each arena comes with distinct rules that affect the way activists can pursue their goals. To pursue a strategy based on litigation, for example, one needs legal expertise to write briefs and make arguments in terms of the law (Meyer and Boutcher 2007); engaging in electoral campaigns places a higher value on the mobilization of people and money. In deciding on arenas, activists assess their opportunities and competencies in various arenas, and the impact that activities in that arena will have on supporters and opponents. As Ganz (2004:185-186) notes, the "possession of domain-relevant skills” allows for creative strategies and problem-solving within particular settings. In selecting venues of interaction with their targets, movements also select levels of action. For example, movements that target legislators may choose to act in national, state or provincial, or municipal legislative arenas. The federal system in the United States, for example, provides multiple layers of government which could conceivably respond to movement demands on many issues. In general, larger venues provide the promise of more substantial responses, but also additional obstacles, including better organized and more powerful opposition. But there are important exceptions: American civil rights activists in the 1950s found the federal government more responsive to their claims than local governments.

Activists may also choose to march in the streets in protest of government actions. Some movements engage in upward or downward "scale shift" from local to national or international arenas, depending on their alliances and perceptions of opportunities (see Tarrow 2005), building on small victories to make larger claims. Some arenas of action are less well defined and noninstitutionalized, as in the case of groups acting in the "public" arena, aiming to influence public opinion, gain supporters, or pressure elites. Depending on their positions relative to their targets, 
collective actors may choose largely institutionalized or non-institutionalized arenas. To the extent that they act in established arenas of power, they are likely to have or develop ties to power holders.

Even as choice of arena poses strategic dilemmas for activists, there are also dilemmas within institutions. Focus on one arena may lead to the neglect of others, as action in some arenas requires significant resources and particular skills. Different institutions move at distinctly different paces, and alternative opportunities can pass unexploited. Further, advantages and expertise developed in one venue may not translate into viable resources in other venues. For instance, organizations such as Greenpeace, which develop extensive expertise for targeting the mass media, may as a result be less capable of building grassroots support. Similarly, organizations that develop extensive lobbying skills may sacrifice the ability to act in

public arenas. Another strategic dilemma associated with choice of arenas is whether to confront opponents directly, for example by battling an opposing movement acting in the legislative arena through lobbying, or to do so indirectly, perhaps through the mass media (Jasper 2004: 13).

\section{Tactics}

Activists also select tactics, which are the specific means of implementing strategy, the forms of collective action taken by movement actors. Movements need to find tactics, such as demonstrations and lawsuits, with which to press claims directed at targets in various arenas. Taylor and Van Dyke (2004) argue that tactics are intentional efforts to create change, which involve contestation with targets and the development of collective identity within challenging groups. Tactical repertoires include "cultural performances” as well as directly targeted actions, 
and both internally and externally targeted actions, which produce both cultural and political changes (Taylor and Van Dyke 2004:268-271). The choice of tactics is a critical one not only because tactics affect outcomes, but because they play a key role in the mobilization of movement support. Movement actors engage in tactics that are primarily intended to mobilize supporters and in others that are aimed at authorities or other actors with the intention of bringing about social change directly. But mobilization tactics and collective action tactics may be distinguished more by intent than effect, and audiences are not hermetically sealed off from one another.

Collective action tactics include direct-action tactics, which bypass established channels of action, and institutionalized tactics, which employ institutionalized procedures for action. Both direct-action and institutionalized tactics may serve mobilization functions as well as more instrumental purposes so that, in practice, the distinction between mobilization and collective action tactics is not always sharp. Recognition of the mobilization functions of many tactics is necessary to an understanding of the tactical choices of movement organizations.

Collective actors face numerous dilemmas in their selection of tactics. The choice of tactics primarily intended to mobilize supporters as opposed to effecting concrete changes is one dilemma; tensions within movements often arise over "whether to play to inside or outside audiences” (Jasper 2004:10). For example, some demonstrations rally movement support, but have little impact on external targets. If insufficient attention is paid to internal mobilization, movements may become unstable and lack the activists needed for some tactics. If too much attention is paid to mobilization needs, movement organizations may neglect effective means of influencing external targets. Another important tactical choice has to do with the selection of 
more disruptive or more orderly tactics. Gamson (1990) found that groups using violent tactics were likely to gain new advantages because their targets were vulnerable. He also found that other, nonviolent types of disruptive activities, such as strikes and boycotts, were likely to produce successes, thus challenging the idea that the most orderly protestors will succeed, at least in circumstances where they enjoy public support (1990: 88).

\section{INFLUENCES ON STRATEGIC CHOICES AND OUTCOMES}

Following from our view of strategy as the product of interactions with authorities, bystanders, supporters and opponents in multi-organizational fields, we can examine influences on strategic choices and their impacts at different levels of interaction: 1) the political and cultural environment, where movement actors encounter political and cultural opportunities and interact with their targets, opponents, bystanders, mass media and potential allies; 2) the movement community, where various organizations and individuals within the movement interact; and 3) the movement organization, where leaders and members of the organization interact. These different levels of interaction are connected--influences at one level affect interactions at another--and strategic choices are influenced by multiple interactions at each level. Histories of interactions and strategic choices and their outcomes influence subsequent strategies by actors in the multi-organizational field. Although it is tempting analytically to view each decision as distinct and discrete, the legacies of the past, including the development of specialized expertise, distinct resources, and a web of relationships with supporters and authorities, constrain subsequent decisions. Analytically, we can view constraints in layers, commencing with large-scale environmental influences, and including movement-level, and organization-level constraints. 


\section{Environmental Influences and Outcomes}

Movement actors formulate strategies in the context of a larger environment, which includes macro- and meso-level structures, political and cultural opportunities, and other actors. The environment consists of any number of relevant actors and elements that affect movement strategies, such as laws and court rulings, repression and support from government actors and other authorities, potential allies, opponents, mass media, public opinion, cultural norms and discourse, master frames and repertoires of collective action. Some elements of the environment, such as laws, may be products of previous rounds of collective action, which limit or expand subsequent strategic choices. Some aspects of the environment, such as freedom of assembly in democratic states, are taken-for-granted features, while others, such as the actions of allies and opponents, are closely watched opportunities and obstacles. Although the notion of a movement environment is potentially too vast and diffuse to provide much explanatory power, we gain analytic leverage if we focus on the ways in which elements of the environment affect the positioning of collective actors, and the ways in which movement actors interact with other actors in their environment. Researchers have raised a number of important questions regarding the influences of environmental structures and relationships on movement strategies.

Political and cultural opportunities include both relatively stable structural elements of the movement environment and more volatile features (Gamson and Meyer 1996). Relatively stable features of political systems and established cultural characteristics help to explain crossnational and cultural differences in strategies, whereas more volatile elements are more useful in explaining differences over time. The structural characteristics of states affect the availability 
and attractiveness of different tactics of influence (Kitschelt 1986; Kriesi et al. 1995). Relative tolerance of more moderate forms of protest is likely to lure activists away from more confrontational strategies of influence (Meyer and Tarrow 1998). In political systems that provide more points of access, collective actors are likely to choose assimilative over confrontational strategies, and movements are more likely to make procedural gains. Various features of political systems, such as the number of political parties and the independence of the legislature and judiciary from the executive, affect choices of strategy and their likely outcomes. Depending on the nature of such political structures, movement actors gain access to different types of resources and occupy different positions vis-à-vis interest groups and authorities. They make different strategic choices, and their strategies are more or less successful, depending on the political structures they confront.

Movements change their strategies over time in response to shifts in the more volatile aspects of political opportunity. As political alignments change and new governments come to power, movements may enjoy greater resources and new positions of access, resulting in new strategic options and outcomes. For example, during the Clinton administration, many environmental leaders in the U.S. became "insiders" and large organizations were inclined to engage in institutionalized tactics. Movements also change strategy in response to increased threats as opposed to heightened receptivity on the part of authorities. Thus, the nuclear freeze movement mobilized as the Reagan administration increased military spending and as elites became divided over the policy (Meyer 1990). Similarly, the abortion rights movement was able to mobilize significant resources during the Reagan years as constituents responded to threats, and these increased resources allowed for new tactical options such as participation in electoral 
politics (Staggenborg 1991).

The cultural context of movement activism, like the political context, influences strategic choices and outcomes. Movement strategies are influenced by both historical and cross-national variations in cultural contexts. Brand (1990) argues that framing strategies vary with shifts in the "cultural climate" such as the change from the "complacency" and "privatistic values" of the 1950s to the idealism and optimism of the 1960s. Cross-nationally, differences in political cultures result in differing movement strategies. For example, Engel (2001) argues that differences in the strategies of gay and lesbian movements in the U.S. and Britain resulted from responses to differing cultural opportunities. Whereas the American movement used a civil rights frame, this frame was out of place in Britain, where arguments were framed in terms of conscience and the acceptability of homosexuality as a private, rather than public, behavior (Engel 2001:136).

Thus, collective actors are limited by structural features of their environments, by political and cultural contexts, and by their perceptions of what strategies are most effective. Political structures and opportunities create routes of influence and set limits on access to resources, allies and authorities. Cultural assumptions and master frames influence movement selection of particular collective action frames. Depending on their assessments of opportunities, and perceptions of what is possible, movement activists make different claims, act in different venues, and employ different tactics. They select strategies and tactics that they believe to be most effective, and that are most familiar to them (Tilly 1978). Within different political and cultural contexts, movement actors develop strategies in interaction with a variety of different actors in their multi-organizational field-authorities, potential allies, opponents, bystander 
publics, and mass media.

Authorities, and often governments, are typically the targets of movement strategies. Movements make initial strategic decisions based on perceptions about the likely responses of authorities as well as other potential allies and opponents in the field. They then adjust their strategies as they interact with their targets and perceive their opportunities to expand or contract in different arenas. At the same time, authorities and other targets of collective action have their own perceptions of movement activists (Skrentny 2006) and they adjust their own tactics and perceptions in response to movement activities. McAdam's (1983) analysis of tactical interaction in the civil rights movement, for example, shows how authorities learn to manage disruptive tactics and opposition, and movements continually devise new tactics in response. A movement's ability to invent tactics and its opponents' ability to adapt to the innovations affect the growth and effectiveness of the movement (1983:736).

Movements and countermovements also forge their strategies in interaction with one another (Meyer and Staggenborg 1996). Initial strategic decisions may be based on political and cultural opportunities, but when a countermovement shows signs of success in a particular arena, the original movement is usually forced to follow suit. A movement will not necessarily adopt the same tactics as its countermovement, however, as the tactics may be deemed illegitimate or ineffective. Opposing movements often monitor the tactics of the other side and analyze their impact as they consider adjustments to their own strategies. Important outcomes, such as major legislation or court rulings, are particularly likely to trigger strategic responses from the opposing movement. If an outcome forecloses action in one venue, the opposing movement is likely to shift to another arena. Moreover, countermovements respond not only to a particular law or 
court ruling, but to prior movement-countermovement interactions and the whole history of movement strategy within communities (Andrews 2002: 918). For example, Andrews details how countermovement forces created segregated academies in Mississippi in response to court victories by the civil rights movement on school desegregation. This strategy was influenced both by a structural factor that created threat, the size of the black community, and by the resources and networks created in earlier movement-countermovement battles. Thus, movement-countermovement interaction created solidarity among white resistors, which enabled them to produce outcomes such as new segregated institutions (Andrews 2002: 930).

Movements also adjust their framing strategies in response to the larger political and cultural environment and the strategies of their opponents. Bernstein (1997) shows that lesbian and gay activists operating in different states, and thus in different political and cultural contexts, adopted distinct approaches to how they presented themselves and their claims, or their "identity deployment.” Where activists lacked political access and significant resources, they were more likely to emphasize their differences with the use of expressive, identity-based tactics. Through their positive or negative interactions with the state, activists in different locales assessed their opportunities for access, formed their identities, and made strategic decisions about how to use their identities. In Oregon, where there was a strong countermovement, Bernstein found that the movement faced internal conflict over strategy. In a study of New York State National Organization for Women's responses to countermovement threats to abortion, McCaffrey and Keys (2000) identify several counter-framing strategies, which motivate supporters in the face of countermovement threat, including polarization and vilification of opponents, debunking of countermovement frames, and saving movement frames that have been challenged. Fetner 
(2001) similarly shows that gay and lesbian activists altered their language and framing strategies in response to countermovement strategies and that, for some issues, the emergence of the countermovement opened up new strategic opportunities for the movement. Dugan (2004) finds that opposing movements monitored one another and retooled their frames, with varying success, based on the larger political context.

Media strategies are often central to the interactions of movements, countermovements and authorities. Opposing movements compete with one another to construct frames that will gain media attention, appeal to the public, and mobilize supporters. In general, mass media have far greater reach and more diverse audiences than internal movement organs, and social movement organizations depend upon mass media to project themselves and their concerns to broader publics. Mass media outlets also have their own concerns about audience and newsworthiness that make it hard for activist groups to present themselves without distortion. Nonetheless, by understanding how particular outlets make decisions about content, learning news routines, and cultivating journalistic contacts, groups can increase their coverage and perhaps even the way in which they are framed (Rohlinger 2006). Movement organizations that actively assess opposition strategies and changes in the political and cultural environment are likely to experience more success in getting favorable media coverage than organizations lacking such media strategies (Rohlinger 2002, 2006; Ryan 1991). Some groups, including Greenpeace, increase their media visibility by providing "appealing copy" and "cultivating friendly relations with key journalists” (Carroll and Ratner 1999:13). Such strategies help movements to gain "standing" and position themselves as important players in the policy-making process (Gamson and Wolfsfeld 1993). 
In addition to authorities, opponents and mass media, movements also make choices in interaction with bystander publics, potential allies, and their own supporters (cf. Turner 1970). Often, tensions arise from attempts to target strategies at multiple groups (Lipsky 1968) because what works in one context can be anathema in another. Strategic actor finds themselves enmeshed in a web of relationships that limit innovation. The tactic that generates attention in mass media can also alienate potential supporters and close doors in mainstream political institutions. In particular, groups face the challenge of pitching to authorities and constituencies simultaneously, while the former values moderation and the latter clarity.

To some extent, choices about strategy are a product of targeted audiences and resources. Barkan (1979) argues that groups with a low potential for disruption combined with low internal resources and skills are most likely to select strategies that will attract public support, while groups with high disruptive potential and internal resources need not be concerned with their public images. In some instances, movements employ strategies in the absence of political opportunities with no realistic chance of success not because activists are irrational, but because the strategies are aimed at mobilizing support rather than achieving other outcomes. For example, Smith (1999) explains how the Canadian gay and lesbian movement used lawsuits to raise consciousness among constituents and the public in the period before the adoption of the Charter of Rights and Freedoms turned legal tactics into weapons for policy change. In effect, activists were mobilizing to generate future opportunities. When movements help to produce outcomes such as court rulings and laws, these outcomes change the political and cultural environment in a number of ways-producing allies, countermovements, and shifts in public opinion. Critical events, including those created by movements, produce significant changes in 
the movement environment, affecting subsequent rounds of movement strategy (Staggenborg 1993).

Thus, various actors and structural features in a movement's environment have an important influence on strategic choices and outcomes. Moreover, the outcomes of strategies affect the availability of subsequent strategic choices. Movements that use strategies to build constituencies later have new possibilities because of newly mobilized resources, but they may also be constrained by the expectations of their funders and constituents. Moveon.org, for example, started as a single-issue group, urging Congress to finish with President Clinton's affair with a White House intern and move on to other issues. Raising money through the internet, the new organization responded to its supporters, gradually becoming a powerful left-liberal force within the Democratic party.

\section{Interorganizational and Movement Community Influences}

The strategies and tactics of movement organizations and activists are also influenced by their allies and the shape of the social movement community they operate within (Buechler 1990; Staggenborg 1998). The movement community consists of networks of actors who support and advance the goals of a movement, including political organizations, cultural groups, institutional allies, service and advocacy organizations, and individual constituents who are not necessarily part of any movement-associated organization. Although movement communities are easiest to conceptualize at the local level, they also exist at regional, national and international levels. Movement communities of compatible social movements are also connected to one another through overlapping members and leaders, resulting in shared culture, organizational structures, 
and tactical repertoires (Meyer and Whittier 1994; Staggenborg 1998). Both formal organizational ties and less formal norms and beliefs operate to constrain strategic choices.

The types of network connections and organizational structures that exist within and across movement communities strongly influence strategic choices. Movement communities may be united by various means, including informal communications networks, friendship and support networks, overlaps in memberships of organizations, movement of paid staff among organizations, central gathering places, and formal coalitions or umbrella organizations. Affective ties within movement communities help to create collective identity and submerged networks that sustain communities and allow for long-term strategies (Roth 2005; Taylor and Rupp 2002). Gould (2002) shows that, within lesbian and gay communities, the political and emotional environment facilitated militant AIDS activism; within ACT UP, emotion work that turned grief to anger allowed for the conversion of community rituals such as memorial vigils into militant actions.

In some movement communities, coordinating groups or leadership teams capable of uniting heterogeneous groups within and across movements play a key role in developing strategies. Gerhards and Rucht (1992) describe the work of "mesomoblization actors" in carrying out strategic campaigns involving multi-movement coalitions. These actors are "groups and organizations that coordinate and integrate micromobilization groups" (558), which activate and inform individual sympathizers and members of the public (569). Mesomobilization actors help create organizational structures capable of mobilizing diverse groups, and they integrate groups ideologically by extending master frames to encompass the concerns of numerous constituents, such as labor unionists, environmentalists and feminists. When campaigns are 
capable of bringing together activists from compatible movements, extensive resources become available for movement strategies.

Organizations also forge formal agreements to work on particular campaigns. Coalition work affects strategic options by increasing available resources and (sometimes) creating bonds of trust among cooperating groups. By pooling their resources, groups acting together can afford more "expensive” strategies than those acting alone, and resources saved by coalition work on one type of tactic can be used on others (Staggenborg 1986). During movement or multimovement campaigns, activists interact with coalition partners from other organizations or movements, forming and strengthening network connections and collective identity. A history of successful coalition work on a campaign, such as a large national demonstration, generates bonds of trust that carry over to subsequent coalition efforts. At the same time, a successful coalition effort can obscure other efforts and even the identity of cooperating groups, leading to a "least common denominator” politics and constricting possible claims and tactics (Meyer and Corrigall-Brown 2005). Similarly, tensions in coalitions, and failed campaigns, have negative effects on subsequent strategic efforts. The history of movement interactions, and strategic choices based on those interactions, affects subsequent resources, networks, and strategic options.

Interactions among activists, and with allies and supporters, enhance resources and provide exposure to new values and ideas regarding arenas, tactics and demands. Network connections at different levels and among different movements and organizations help to diffuse tactical repertoires and collective identities. Scale shifts are most likely when local and national or international activists are connected to one another, resulting in new arenas, targets, claims 
and identities (Keck and Sikkink 1998; Tarrow 2005). Movement organizations are likely to adopt some of the strategies of other groups and allies with which they interact, or to deliberately devise a strategic division of labor within the movement community. In a study of British environmental organizations, Rootes (2006) shows how the agendas of major groups are shaped by their interactions and partnerships with a variety of other actors, including government officials and agencies and sometimes corporations, as well as local supporters, other environmental groups, non-profit organizations, labor unions, and global justice movement organizations. Network connections have drawn environmental organizations such as the World Wildlife Fund (WWF) and Friends of the Earth (FoE) into participation in international forums and influenced them to take up issues of sustainable development and global justice. Greenpeace, in contrast to WWF and FoE, lacks a local mass-membership base and engages in fewer long-term partnerships with other groups; consequently, the group has made fewer changes in its agenda to accommodate issues of development and social justice (Rootes 2006; also see Diani 1995).

Connections among individuals and organizations also affect the likelihood that movements will select strategies that exploit cultural and political opportunities. In her comparative study of the American and Swiss suffrage movements, Banaszak (1996) argues that the U.S. movement was more opportunistic and innovative strategically-and thus more successful-than its Swiss counterpart. In the United States, suffragists maintained ties with activists in other national and local movements, particularly temperance and abolition, and connections among groups and individuals provided intelligence about politics, tactics, new ideas, occasional resources, and inspiration. In Switzerland, in contrast, the movement grew in 
isolation from other movements that could have had a similar effect. The point is that the composition of the field of actors affects the strategies of everyone within that field.

The history of interactions with activists in other locations and from other social movements, as well as with other actors such as police, influences strategic choices. In a study of the development of gay pride parades to commemorate the Stonewall riots, Armstrong and Crage (2006) show that activists in San Francisco failed to commemorate earlier police raids in such a manner, preferring instead to employ more moderate tactics of accommodation. Their strategic choices were influenced both by relatively good relations with the city's police, which had resulted in the successful use of moderate tactics in the past, and by a lack at the time of sufficient ties to gay activists elsewhere in the country and to other social movements. By the time of the Stonewall riots in 1969, there were extensive connections between gay liberation activists and New Left movements, as well as a radical political culture in New York, which encouraged a radical response that resonated with activists across the country. As interactions and alliances change over time, both past experiences and current relations influence strategic choices.

As movements expand, organizations may develop a tactical division of labor so that new organizations can distinguish themselves from existing ones, and avoid competition for membership and funding (Gerlach and Hine 1970). Organizations adopting moderate tactics may experience support and success as a result of the positive "radical flank effects" created by more radical tactics (Haines 1984), and some established groups deliberately aid direct-action groups in recognition of this effect (Rootes 2006:778). Zald and McCarthy (1980) focus on competition among movement organizations for resources, participants and legitimacy as a 
source of tactical differentiation, using business metaphors to illustrate their analysis. Insofar as the potential pool of movement supporters is heterogeneous, movement organizations develop different "products" to appeal to different types of potential supporters (1980:6). Broad shifts in the available of resources to a particular sector is largely a function of changes in political opportunity. As resources appear plentiful, groups can differentiate and populate without threatening their allies. When, however, available resources shrink, competition within the market increases and groups will increasingly differentiate themselves from others (Meyer and Imig 1993). Zald and McCarthy suggest that movement organizations will cooperate, however, when they develop task specializations that are distinct but compatible, allowing them to combine resources to achieve common goals with "similar tactical formulas" (1980:11).

\section{Internal Organizational Influences}

Movement strategies are most frequently formulated by activists within social movement organizations (SMOs), and the organizational structures, emotional climates, resources and ideologies of SMOs shape their view of available strategic options as well as their choices. Like environmental dynamics and the structures of movement communities, internal organizational characteristics act as filters for strategic choices. As Jo Freeman (1979) argues, we can think about strategic decision making by SMOs as limited by certain factors; in her model, strategic decisions are affected by available resources, constraints on the use of resources, SMO structure and internal environment, and expectations about potential targets.

Resources are clearly central to strategy insofar as SMOs can only select tactics they can support with sufficient money, numbers of people, expertise, and commitment. Yet, as Freeman 
(1979:179) notes, all resources come with constraints, which form "a kind of filter between resources and SMOs.” Beyond material resources, other "limiting factors” for movement strategies, such as ideology, place some issues, alliances, and tactics off limits (Turner 1970: 151-153). Freeman, building on the work of Ralph Turner, suggests that constraints include values, past experiences, reference groups, expectations, and relations with target groups (1979:177). As these discussions suggest, SMO strategies are always formulated in interaction with actors both inside and outside the organization. And, as Marshall Ganz $(2000,2004)$ argues, it is not simply resources that drive effective strategy, but "resourcefulness" in developing "strategic capacity.”

As activists create organizations, their structures and rules of governance operate as both constraints and resources. We saw, for example, that Moveon.org's focus on internet democracy pushed it toward the left, but leaders often view their memberships, at least when active, as constraints and brakes (Kretschmer and Meyer 2007; Staggenborg 1988). Organizational structures, particularly those that support effective "leadership teams," are an important element of strategic capacity (Ganz 2000; Reger and Staggenborg 2006). SMOs need to provide opportunities for participants to learn skills and develop leadership qualities, so that new leaders are continually trained. They need to find ways to get activists involved, both in routine organizational maintenance and in collective action campaigns. They need to create a division of labor that disperses responsibilities efficiently while maintaining accountability and preventing the burnout that comes from over-reliance on select individuals. SMOs need to provide forums for internal debate, education, and decision-making about mobilization and collective action strategies. Effective leaders need to maintain contacts with constituents and other actors such as 
sympathetic authorities who can provide information relevant to strategic choices.

Organizational decision-making structures need to give leaders authority, but also keep them accountable to their constituents. Ganz argues that diverse leaders with different types of external ties working in a team provide a range of information that enables organizations to make good strategic choices:

Strategic capacity is greater if a leadership team includes insiders and outsiders, strong and weak network ties, and access to diverse, yet salient, repertoires of collective action and also if an organization conducts regular, open, authoritative deliberation, draws resources from multiple constituencies, and roots accountability in those constituencies (2000:1005).

As Ganz found in the case of the United Farm Workers compared to a better funded AFL-CIO rival, effective organizational structures and strategic capacity can result in more successful campaigns than financial resources alone. We could also note that the UFW was less encumbered by its supporters' expectations and constraints than the AFL-CIO.

A variety of different types of organizational characteristics influence strategic choices. While some organizational features, such as the ability to develop leadership teams, increase strategic capacity generally, others make SMOs better suited to certain types of strategies than others. Organizational variations include the extent and type of formalization or bureaucratization; professionalization of leadership; grassroots participation; centralization and hierarchy in decision-making structures; links among organizational levels, such as chapters and national headquarters; and forums available for decision-making and deliberation. These features affect strategic choices of venues, tactics and demands by limiting resources, 
information and input from participants, and ability to recognize and respond to environmental threats and opportunities.

As SMOs make organizational and strategic choices, those choices shape subsequent strategic choices and options, although how they do so is not always clear. Some analysts suggest that centralization and bureaucratization lead to a decline in insurgency as oligarchic leaders become more conservative in their tactics and focused on organizational maintenance (Michels 1915; Piven and Cloward 1977), while others point to the more positive association of bureaucracy and centralized decision-making with movement survival and success (Gamson 1990). In the case of the American abortion conflict, pro-choice groups began to professionalize their leadership and formalize their structures after legalization of abortion in 1973 in order to meet countermovement challenges; these organizational changes stabilized the movement and also facilitated the use of tactics in institutionalized arenas such as the courts and legislatures (Staggenborg 1988, 1991). In the environmental movement, Rucht (1995) shows how the highly centralized Greenpeace engaged in professionally orchestrated, carefully planned and targeted tactics, which led the organization to avoid party politics and political positions that would threaten favorable media coverage and public sympathy. In contrast, the extremely decentralized Earth First! engaged in controversial direct action and civil disobedience tactics unencumbered by concerns with favorable media coverage and the need to attract mass donations (1995:80).

Some groups, particularly feminist ones, have experimented with "hybrid" forms (Bordt 1997). In a comparison of two feminist organizations, Staggenborg (1989) finds that formalization of offices and division of labor are associated with efficiency in decision-making 
and task performance and an ability to engage in large-scale, externally targeted projects, but that formalized decision-making processes can limit the involvement of members and hence their strategic input. Centralized decision-making power helps to concentrate resources and reduce internal competition and conflict, but may also narrow demands and concentrate resources on organizational maintenance. Informal and decentralized organization can facilitate participation by more activists and use of a wider range of innovative tactics, but decentralized decisionmaking and the absence of a formal division of labor can also lead to financial instability, internal conflict, lack of coordination with subunits, and problems in implementing strategies. The combination of formalization and decentralization, while difficult to achieve, might provide SMOs with the advantages of both stability and innovation (1989:89).

Although external actors and events often demand responses, internal organizational arrangements affect the ability of SMOs to respond effectively to their environments. In her study of the framing battles of gay rights activists and their Christian Right opponents over an anti-gay voter initiative, Dugan (2004) shows that the gay rights campaign failed to respond effectively to its opponents in part because a handful of leaders made decisions without consulting widely-a situation that might have been remedied by an organizational structure that nurtured a diverse leadership team. In her study of movement-countermovement framing contests in the abortion conflict, Rohlinger (2002) shows that the National Organization for Women (NOW) was more effective than Concerned Women for America (CWA) in garnering media coverage because NOW's formalized organizational structure, which featured a communications department, enabled the organization to communicate better with the media than did CWA's structure, which lacked such a department and focused more on grassroots 
organizing than professionalization. For other types of strategies, grassroots organizing is an asset and the lack of grassroots connections may prevent use of a tactic or frame. For example, Rootes (2006) found that Greenpeace, which lacks extensive local participation, was less likely than FoE to be receptive to the views of grassroots activists. In FoE, grassroots activists, as well as international partners, pushed the organization to expand its agenda to include new global justice issues while Greenpeace generally maintained its longstanding concerns.

Both ideological and structural factors influence the strategic responses of SMOs. In another study of Greenpeace and Friends of the Earth, Carmin and Balser (2002) find that experience, core values and beliefs, environmental philosophy and political ideology all act as filters that shape perceptions as to the efficacy and acceptability of particular tactics. For example, in its early years, a core belief in the legitimacy of legal and political structures led FoE to use institutionalized tactics, while core beliefs about justice and the ability of individuals to make a difference led Greenpeace to "bear witness" through nonviolent direct action. In a study of tactical conflicts among environmental organizations over the North American Free Trade Agreement (NAFTA), Dreiling and Wolf (2001) similarly acknowledge the role of filters such as ideology and identity, but stress material and organizational variables in explaining organizational stances on NAFTA. Opponents of NAFTA were likely to draw their support from grassroots members, while pro-NAFTA organizations often relied on external revenue, such as corporate donations, and shared directors with pro-NAFTA organizations. SMOs that rely on external funding and have inclusive boards of directors and director interlocks with elites and policy bodies are likely to adopt strategies in line with those linkages and dependencies (2001:47). Whether or not an organization has a tax exempt status, runs a political action 
committee, or relies on public support or grassroots members are all influences on its strategic choices (Dreiling and Wolf 2001:49; McCarthy, Britt and Wolfson 1991).

\section{CONCLUSION}

Activists make strategic decisions within particular contexts in interaction with other actors in the multi-organizational field. Importantly, however, decisions about demands, tactics, and arenas are not made anew, but within the constraints created by previous decisions and environmental and organizational structures. Studies of movement strategies are important as a means of understanding what routes of influence are possible for collective actors based on these constraints. In some instances, movement actors can shift the structure of constraints by, for example, structuring their organizations differently, cultivating different alliances, or changing elite perceptions. In other instances, they need to figure out how best to work within structural constraints. Studies of strategic decision-making are needed to analyze the nature of structural constraints on movement strategy, and the ways in which strategies alter those constraints and effect change.

Strategic action involves series of interactions with authorities, supporters, bystanders, opponents, media and potential allies. We argue that these interactions are affected by environmental, community and organizational factors, which all need to be examined in any study of strategic decision-making. We summarize the set of related decisions activists make in terms of demands, arenas and tactics. We propose using these elements of strategy as visible expressions of strategic negotiations, which also involve targeting, timing, framing and other strategic choices. We are not suggesting a mechanical framework for the study of strategy; any 
empirical study needs to capture the complexity and emotionality of strategic choice and the ongoing interactions involved in collective action.

The focus on a strategic field of actors which shapes available choices should allow us to develop a meaningful theory of social movement strategy as well as a series of propositions that can guide empirical research on strategy. For example, if a greater number of organizational ties operates as a constraint, we would expect innovation within a movement to come primarily from new organizations. We hope that our effort to conceptualize key elements of strategy and influences on strategic decision-making will stimulate new theory and research. 


\section{References}

Andrews, Kenneth T. 2002. "Movement-Countermovement Dynamics and the Emergence of New Institutions: The Case of "White Flight" Schools in Mississippi." $\underline{\text { Social Forces }}$ 80(3):911-936.

Animal Liberation Brigade. “Communiqué.”

http://www.animalliberationpressoffice.org/communiques/2007-06-27_rosenbaum.htm. Accessed July 25, 2007.

Armstrong, Elizabeth A. and Suzanna M. Crage. 2006. "Movements and Memory: The Making of the Stonewall Myth." American Sociological Review 71:724-751.

Ash, Roberta. 1972. Social Movements in America. Markham Publishing Co.

Barkan, Steven E. 1979. "Strategic, Tactical, and Organizational Dilemmas of the Protest Movement Against Nuclear Power." Social Problems 27(1):19-37.

Bernstein, Mary. 1997. "Celebration and Suppression: The Strategic Uses of Identity by the Lesbian and Gay Movement." American Journal of Sociology 103(3):531-565.

Bordt, Rebecca L. 1997. The Structure of Women's Nonprofit Organizations. Bloomington, IN: Indiana University Press.

Brand, Karl-Werner. 1990. "Cyclical Aspects of New Social Movements: Waves of Cultural Criticism and Mobalization Cycles of New Middle-class Radicalism." Pp. 23-42 in Challenging the Political Order: New Social and Political Movements in Western Democracies, edited by R. J. Dalton and M. Kuechler. New York: Oxford University Press.

Buechler, Steven M. 1990. Women's Movements in the United States. New Brunswick, NJ: 


\section{Rutgers University Press.}

Carmin, Joann and Deborah B. Balser. 2002. "Selecting Repertoires of Action in Environmental Movement Organizations." Organization \& Environment 15(4):365-388.

Carroll, William K. and R.S. Ratner. 1999. "Media Strategies and Political Projects: A Comparative Study of Social Movements." Canadian Journal of Sociology 24(1):1-34.

Diani, Mario. 1995. Green Networks. Edinburgh: Edinburgh University Press.

Dreiling, Michael and Brian Wolf. 2001. "Environmental Movement Organizations and Political Strategy." Organization \& Environment 14(1):34-54.

Dugan, Kimberly B. 2004. "Strategy and "Spin": Opposing Movement Frames in an Anti-Gay Voter Initiative." Sociological Focus 37(3):213-233.

Engel, Stephen M. 2001. The Unfinished Revolution: Social Movement Theory and the Gay and Lesbian Movement. Cambridge: Cambridge University Press.

Fendrich, James Max. 1993. Ideal Citizens: The Legacy of the Civil Rights Movement. Albany: State University of New York Press.

Fetner, Tina. 2001. "Working Anita Bryant: The Impact of Christian Anti-Gay Activism on Lesbian and Gay Movement Claims." Social Problems 48(3):411-428.

Freeman, Jo. 1979. "Resource Mobilization and Strategy: A Model for Analyzing Social Movement Organization Actions." Pp. 167-189 in The Dynamics of Social Movements:

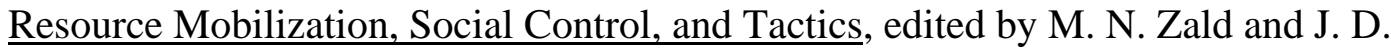
McCarthy. Cambridge, Massachusetts: Winthrop.

Gamson, William A. 1990. The Strategy of Social Protest, Second Edition. Belmont, CA: Wadsworth. 
Gamson, William A. and David S. Meyer. 1996. "Framing Political Opportunity." Pp. 275-290 in Comparative Perspectives on Social Movements: Political Opportunities, Mobalizing Structures, and Cultural Framings, edited by D. McAdam, J. D. McCarthy, and M. N. Zald. Cambridge: Cambridge University Press.

Gamson, William A. and Gadi Wolfsfeld. 1993. "Movements and Media as Interacting Systems.” Annals of the Academy of Political and Social Science 528: 114-125.

Ganz, Marshall. 2000. "Resources and Resourcefulness: Strategic Capacity in the Unionization of California Agriculture, 1959-1966." American Journal of Sociology 105(4):1003-62. . 2004. "Why David Sometimes Wins: Strategic Capacity in Social Movements." Pp. 177198 in Rethinking Social Movements, edited by J. Goodwin and J. M. Jasper. Lanham, MD: Rowman and Littlefield.

Gerhards, Jurgen and Dieter Rucht. 1992. "Mesomobilization: Organizing and Framing in Two Protest Campaigns in West Germany." American Journal of Sociology 98(3)Nov.:555595.

Gerlach, Luther and Virginia H. Hine. 1970. People, Power, Change: Movements of Social Transformation. Indianapolis, Indiana: Bobbs-Merrill.

Gould, Deborah B. 2002. "Life During Wartime: Emotions and the Development of ACT UP." Mobilization 7 (2):177-200.

Gordon, Larry. 2007. “\$110,000 Reward offered in Attempted Bombing at UCLA Doctor’s Home.” Los Angeles Times. July 25.

Gornick, Janet C. and David S. Meyer. 1998. “Changing Political Opportunity: The Anti-Rape Movement and Public Policy,” Journal of Policy History 10 (4): 367-398. 
Haines, Herbert H. 1984. "Black Radicalization and the Funding of Civil Rights: 1957-1970." Social Problems 32(1):31-43.

th to Collective Action: Looking for Agency in Social-Movement Choices." Mobilization 9(1):1-16.

Jenkins, J. Craig. 1981. "Sociopolitical Movements." Pp. 81-154 in Handbook of Political Behavior, vol. 4, edited by S. L. Long. New York: Plenum Publishers.

Keck, Margaret E. and Kathryn Sikkink. 1998. Activists beyond Borders. Ithaca: Cornell University Press.

Kitschelt, Herbert P. 1986. "Political Opportunity Structures and Political Protest: Anti-Nuclear Movements in Four Democracies." British Journal of Political Science 16(1):57-85.

Kretschmer, Kelsy and David S. Meyer. 2007. "Platform Leadership: Cultivating Support for a Public Profile.” American Behavioral Scientist 50 (10): 1395-1412.

Kriesi, Hanspeter, Ruud Koopmans, Jan Willem Duyvendak, and Marco G. Giugni. 1995. The Politics of New Social Movements in Western Europe. Minneapolis: University of Minnesota Press.

Lipsky, Michael. 1968. "Protest as a Political Resource." American Political Science Review 62:1144-1158.

McAdam, Doug. 1983. "Tactical Innovation and the Pace of Insurgency." American Sociological Review 48(6):735-754.

McCaffrey, Dawn and Jennifer Keys. 2000. "Competitive Framing Processes in the Abortion Debate: Polarization-vilification, Frame Saving, and Frame Debunking." Sociological Quarterly 41(1):41-61.

McCarthy, John David W. Britt and Mark Wolfson. 1991. "The Institutional Channeling of 
Social Movements by the State in the United States." Research in Social Movements, Conflicts and Change 13:45-76.

Michels, Robert. 1915. Political Parties. New York: Free Press.

Meyer, David S. 1990. A Winter of Discontent: the Nuclear Freeze and American Politics. New York: Praeger.

Meyer, David S. 2007. The Politics of Protest: Social Movements in America. New York: Oxford University Press.

Meyer, David S. and Steven A. Boutcher. 2007. "Signals and Spillover: Brown v. Board of Education and Other Social Movements,” Perspectives on Politics 5 (1): 81-93.

Meyer, David S. and Douglas R. Imig. 1993. "Political Opportunity and the Rise and Decline of Interest Group Sectors." Social Science Journal 30 (3): 253-270.

Meyer, David S. and Suzanne Staggenborg. 1996. "Movements, Countermovements, and the Structure of Political Opportunity." American Journal of Sociology 101(6):1628-1660.

Meyer, David S. and Sidney Tarrow, ed., 1998. The Social Movement Society. Lanham, Maryland: Rowman \& Littlefield.

Meyer, David S. and Nancy Whittier. 1994. "Social Movement Spillover." Social Problems 41(2):277-298.

Piven, Frances Fox and Richard A. Cloward. 1977. Poor People's Movements: Why They Succeed, How They Fail. New York: Vintage Books.

Reger, Jo and Suzanne Staggenborg. 2006. "Patterns of Mobilization in Local Movement Organizations: Leadership and Strategy in Four National Organization for Women Chapters." Sociological Perspectives 49(3):297-323. 
Rohlinger, Deana A. 2002. "Framing the Abortion Debate: Organizational Resources, Media Strategies, and Movement-Countermovement Dynamics." Sociological Quarterly 43(4):479-507.

Rohlinger, Deana A. 2006. "Friend and Foe: Media, Politics, and Tactics in the Abortion War." Social Problems 53: 537-561.

Rootes, Christopher. 2006. "Facing South? British Environmental Movement Organisations and the Challenge of Globalisation." Environmental Politics 15(5):768-786.

Roth, Silke. 2005. "Sisterhood and exclusionary solidarity in a labor women's organization." Pp. 189-206 in Emotions and Social Movements, edited by H. Flam and D. King. London: Routledge.

Rucht, Dieter. 1990. "The Strategies and Action Repertoires of New Movements." Pp. 156-175 in Challenging the Political Order: New Social and Political Movements in Western Democracies, edited by J. D. a. M. K. Russell. New York: Oxford University Press. Rucht, Dieter. 1995. "Ecological Protest as Calculated Law-breaking: Greenpeace and Earth First! in Comparative Perspective." Pp. 66-89 in Green Politics Three, edited by R. Wolfgang. Edinburgh: Edinburgh University Press.

Ryan, Charlotte. 1991. Prime Time Activism: Media Strategies for Grassroots Organizing. Boston: South End Press.

Severson, Kim. 2007. “Bringing Moos and Oinks into the Food Debate.” The New York Times. July 25.

Smith, Miriam. 1999. Lesbian and Gay Rights in Canada. Toronto: University of Toronto Press. Staggenborg, Suzanne. 1986. "Coalition Work in the Pro-Choice Movement: Organizational and 
Environmental Opportunities and Obstacles." Social Problems 33(5):374-390.

. 1988. "The Consequences of Professionalization and Formalization in the Pro-Choice

Movement." American Sociological Review 53:585-605.

1989. "Stability and Innovation in the Women's Movement: A Comparison of Two

Movement Organizations." Social Problems 36(1):75-92.

1991. The Pro-Choice Movement: Organization and Activism in the Abortion Conflict.

New York: Oxford University Press.

. 1993. "Critical Events and the Mobilization of the Pro-Choice Movement." Research in

Political Sociology 6:319-345.

1998. "Social Movement Communities and Cycles of Protest: The Emergence and

Maintenance of a Local Women's Movement." Social Problems 45(2):180-204.

Tarrow, Sidney. 2005. The New Transnational Activism. New York: Cambridge University

Press.

Taylor, Verta and Leila J. Rupp. 2002. "Loving Internationalism: The Emotion Culture of Transnational Women's Organizations, 1888-1945." Mobilization 7 (2):141-158.

Taylor, Verta and Nella Van Dyke. 2004. "'Get Up, Stand Up': Tactical Repertoires of Social Movements." Pp. 262-293 in The Blackwell Companion to Social Movements, edited by David A. Snow, Sarah A. Soule, and Hanspeter Kriesi. Oxford: Blackwell.

Tilly, Charles. 1978. From Mobilization to Revolution. Reading, Mass.: Addison/Wesley Publishing Co.

Turner, Ralph H. 1970. "Determinants of Social Movement Strategies." Pp. 145-164 in Human Nature and Collective Behavior: Papers in Honor of Herbert Blumer, edited by S. 
Tamotsu. Englewood Cliffs, NJ: Prentice-Hall.

Whalen, Jack and Richard Flacks. 1989. Beyond the Barricades: The Sixties Generation Grows Up. Philadelphia: Temple University Press.

Zald, Mayer N. and John D. McCarthy. 1980. "Social Movement Industries: Competition and Cooperation Among Movement Organizations." in Research in Social Movements, Conflicts and Change, vol. 3, edited by L. Kriesberg. Greenwich, Conn.: JAI Press. 